\title{
Gerd Theissen's Rich-Poor Notion Revisited: A Rhetorical Analysis of 1 Corinthians 11:17-22
}

Sin Pan Ho

Lutheran Theological Seminary, Hong Kong

\begin{abstract}
This article argues that Paul's rhetorical purpose of the Lord's Supper in 1 Cor 11:17-34 is his ongoing anti-idol rhetoric in 1 Cor 10. It explains well the phenomenon stated in 1 Cor 11:17-22 that early comers ate all the food and did not show concern for the needs of latecomers. The generally accepted notion of rich-poor disparity does not hold, for the despised latecomers were probably composed both of rich and poor, not the poor alone. Paul continues to expound his brief teachings in 10:20-21 and articulate them in constructive terms in 1 Cor 11:17-34. As a result, Paul's rhetorical purpose in 1 Cor. 11:17-34 is primarily about the transformation of worship attitudes of the first readers who were formerly idol-worshippers. As a result, this reading renders Paul's teachings in 1 Cor $11-14$ more consistent and united.
\end{abstract}

Keywords: 1 Cor 11:17-34; divisions; Lord's Supper; Rich-poor; Gerd Theissen; cultic meals

1 Corinthians 11:17-34 is a witness to early Christian gathering. It is probably the earliest witness to Christian gathering in the first century Roman Corinth. Corinthians met regularly together outside working hours and this involved eating together. The meeting time was in the evening. Hence Paul called this gathering the Lord's Supper ( $\delta \varepsilon \tilde{\pi} \pi v o v$ in 11:20). It refers to the main meal of a 
day that people gathered together to eat towards evening in antiquity. ${ }^{1}$ The problem Paul addressed here was divisions ( $\sigma \chi i \sigma \mu \alpha \tau \alpha, 11: 18)$ taking place during the supper in the Corinthian evening gathering. The reasons why there were divisions in eating is a critical question for identifying the rhetorical purpose of Paul in 1 Cor 11:17-34, and consequently the teachings of Paul about the Lord's Supper.

\section{$1 \quad$ Rich-Poor Disparity? Text and Contexts Revisited}

Since the proposal of Gerd Theissen (1982), the notion of economic disparity between rich and poor, or unequal social status, has been generally accepted by NT scholars as the explanation for the divisions in the gathering of Lord's Supper in the Corinthian church. ${ }^{2}$ The central irregularity underlying the divisions of the Corinthian church which Paul rebuked was negligence of the poor by the wealthy members. Although there may be some slightly different deviating reconstructions of the Lord's Supper in Roman Corinth, Theissen's classical rich-poor notion $(1982,160)$ is still representative:

Some wealthier Christians have made the meal itself possible through their generosity, providing bread and wine for all. What was distributed is declared by means of the words of institution to be the Lord's and given to the congregation. Thus, in conjunction with this common meal there could take place a private meal because the starting point of the Lord's Supper was not regulated, and up to this starting point (that is, until the words of institution) what had been brought and provided was private property. More importantly, this distinction was possible because the wealthier Christians ate other food in addition to the bread and wine, and the words of institution made no provision for sharing this with the fellowship.

Theissen's interpretation of divisions in the Lord's Supper is mainly grounded on his reconstruction of the socio-economic context in Roman Corinth

Justin the Martyr also witnessed that Christian gatherings met regularly at night: "Or do you also condemn our customs and morals? This is what I say, lest you, too, believe that we eat human flesh and that after our banquets we extinguish the lights and indulge in unbridle sensuality" (Dial. 10; English translation from Slusser, 2003, p. 18).

2 Cf. Meeks, 1983, pp. 67-69; Mitchell, 1991, pp. 156-157; Martin, 1995, pp. 73-76; Hays, 1997, pp. 195-197; DeSilva, 2000, p. 75; Garland, 2003, pp. 542-544; McRae, 2011; Alikin, 2010, p. 105; Finney, 2012, pp. 171176; Fee, 2014, pp. 601-603; Fuad, 2019, pp. 207 b.

William Loader, Boris Repschinski, Eric Wong (Eds.)

Matthew, Paul, and Others: Asian Perspectives on New Testament Themes

(C) 2019 innsbruck university press, ISBN 978-3-903187-66-5, DOI 10.15203/3187-66-5 
in Paul's time. Thus, the central irregularity of the Lord's Supper is about the social tensions between the rich and poor (Theissen, 1982, p. 164). Paul's resolution was social integration: "Paul moves the sacrament to the centre to achieve a greater social integration" (Theissen, 1982, p. 167). He urges the wealthy Christians to realize a community of love through the gracious sharing of material food and concern for the poor.

In terms of the text, the only textual evidence which supports the rich-poor notion is 11:22: the rich (those who have) did not show concern for the poor

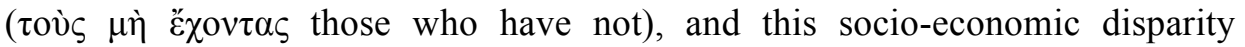
resulted in the divisions of the Lord's Supper depicted in 1 Cor 11:17-22. Wayne Meeks's interpretation $(1983,68)$ best represents and summarizes this rich-poor reading based on the text 11:22 alone:

The last phrase, hoi me echontes, could be read quite concretely as continuing the oikias ouk echete of the preceding question; that is, those who have houses are blamed for humiliating those who do not. More likely, the phrase is to be taken absolutely, "the have-nots," that is, the poor. Either way, this verse makes it clear that the basic division is between the (relatively) rich and the (relatively) poor.

\section{Rhetorical Analysis of the Text against Rich-poor Reading}

Through delving into the rhetorical analysis of the text 1 Cor 11:17-34, this rich-poor reading, however, may now be found wanting. The main reason is that

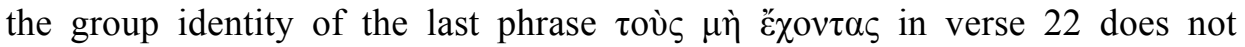
designate ONLY the poor who have nothing to eat in their ordinary lives.

Verse 22 should not be read in isolation from the surrounding literary context. There are two occurrences of $\gamma \alpha \grave{\alpha} \rho$ at the beginning of verse 21 and verse 22. They indicate that verse 22 continues to explain Paul's judgment in v.20: "When you come together, it is not really to eat the Lord's Supper." Paul describes the phenomenon of their gathering before or during the Lord's Supper in verse 21. Then Paul raises four rhetorical questions in verse 22 in which answers are already implicit. The subject 'you' in verse 22 refers to the 'you' stated in verse 20 as well as the two groups (hungry and drunk group) in verse

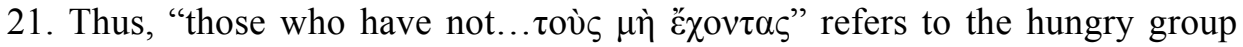
that is antithetical to the two clauses "those who have food to eat and drink (21)" and "when you gather together"(20). In other words, the phrase $\tau$ où $\varsigma \mu \grave{\eta}$

William Loader, Boris Repschinski, Eric Wong (Eds.)

Matthew, Paul, and Others: Asian Perspectives on New Testament Themes

C 2019 innsbruck university press, ISBN 978-3-903187-66-5, DOI 10.15203/3187-66-5 
Ě $\chi 0 v \tau \alpha \varsigma$ at the final rhetorical question of verse 22 does not mean "those who have not their own homes to eat." It should mean simply "those who have nothing to eat when you gather together."

Paul's concluding remark further confirms that the hungry group, or "those who have not $\tau$ où $\varsigma$ ì है $\chi 0 v \tau \alpha \varsigma$ ", does not refer to a poor group who have nothing to eat in their ordinarily lives: "If anyone is hungry, let him eat at home

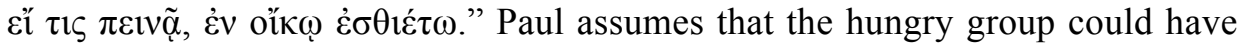
their supper at their own homes. Therefore, the only textual evidence of richpoor notion on verse 22 is deemed unwarranted.

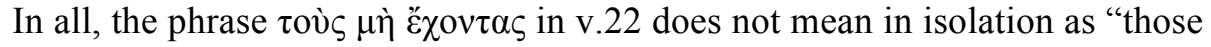
who are have nots", taking it simply as poor people who have nothing to eat; it means "those who have nothing to eat in the gathering of the Lord's Supper."

\section{Social-Economic Contexts Against Rich-poor Reading}

Now I delve into the social contexts to identify who these hungry group members were. Were they regarded primarily as poor people in the city of Roman Corinth, as the rich-poor notion suggests? The rich-poor notion assumes that "those who have nothing to eat when you gather together" were confined mainly to the poor. The poor, due to working obligation, came late to the gathering. Or the rich could bring their food with abundance to the gathering place to eat, while "those who have nothing to eat when you gather together", i.e. the poor, could only bring food with scarcity to the meeting place. ${ }^{3}$

\section{Latecomers could be Rich People}

Through my study of working activities of ordinary people in Roman Corinth in antiquity, this assumption that equates latecomers with the poor, however, does not hold. Latecomers who had nothing to eat in the gathering were not confined only to the poor. They could probably be poor AND rich people.

3 These two possible scenarios depend on the translation of the verb $\pi \rho \circ \lambda \alpha \mu \beta \alpha ́ v \varepsilon 1$ in v.21. Some emphasize the prefix $\pi \rho$ ò- and so translate it as "take beforehand". Then it means they eat their own meals before the Lord's Supper. Others take from the reference of this verb in Gal 6:1, the only other instance this verb exists in Pauline letters, or from some inscriptions, that this verb does not connote any temporal sense, simply means "take". Then the sentence refers to the readers eating their own meals brought to the gathering during the Lord's Supper. These two possibilities, however, do not alter the arguments in this paper.

William Loader, Boris Repschinski, Eric Wong (Eds.)

Matthew, Paul, and Others: Asian Perspectives on New Testament Themes

(C) 2019 innsbruck university press, ISBN 978-3-903187-66-5, DOI 10.15203/3187-66-5 
Economic activities of Roman Corinth mainly focused on commerce, trade, manufacturing and services. After the Roman Empire founded this city in 44 B.C., Corinth was developed as a prosperous entrepôt centre between the Eastern and Western part of the Roman Empire. Roman Corinth was, first of all, a commercial centre in the Mediterranean world. Being well-known for her location as a knot connecting East and West through sea-routes with two harbours Kenchreai and Lechaion, and South and North through the land, many goods were being imported and exported through Roman Corinth. Strabo witnessed this phenomenon in the first century of Corinth in his travel notes:

Corinth is called 'wealthy' because of its commerce. It is located on the Isthmos and is master of two harbors, one to Asia, the other near to Italia, making the interchange of cargo easy between places so far apart. It was desirable to the merchants both from Italia and Asia to avoid the sail around Maleai, and to land their cargo at Corinth, and to dispose of it. (Strabo 8.6.20; English translation from Roller, 2014, 374)

There were large scale trade activities in the eastern sea-port, Kenchreai and the western one, Lechaion. It implies that one significant economic activity that Corinthians participated in was with trade or transit goods of this entrepôt, like Hong Kong people in modern times. There were great emporia situated in these two harbours. They fostered numerous economic activities and so various opportunities were available for Corinthians to make a living related to trade in both the countryside and town.

David K. Pettegrew $(2014,140)$ has remarked on the most common types of work of Corinthians: As such, Kenchreai and Lechaion created the economic space for business for a wide range of individuals linked to trade: wholesaler dealers, financiers, ship owners, traders, landowners, middle men, retailers, craft specialist, sailors and rowers, and many others.

If the first readers were engaged in trade or the transit of goods of this entrepôt, they were not able to determine the time when they could be off work. It was because their off-working hours depended on the time when the goods were delivered to their place. These people involved in trade business might constitute the hungry group who came late to the Lord's Supper, or they did not have time to make their meal at home but went directly to the evening Christian gathering right after their work. However, this group of people could be wholesale dealers, ship owners or craft specialists who were wealthy as well as

William Loader, Boris Repschinski, Eric Wong (Eds.)

Matthew, Paul, and Others: Asian Perspectives on New Testament Themes

(C) 2019 innsbruck university press, ISBN 978-3-903187-66-5, DOI 10.15203/3187-66-5 
those unskilled workers, sailors or rowers who were not rich. They were not necessarily poor people.

Besides a commercial centre, Roman Corinth was well-known for her service economy. Municipal services were prevalent in this city, for she was the provincial capital of Achaea. Those who worked in municipal services were Roman citizens. For the majority of freedmen who were not Roman citizens, they were probably involved in tourism, which was another significant economic activity of the service sector. The empire-wide event, the Isthmian Games, took place in Roman Corinth once every two years. It indicated that the service industry related to tourism such as accommodation, bathing, entertainment, restaurants and handicraft shops flourished in this city.

Like commerce and trading activities, it was difficult for people involved in the service economy to control their own working time. Corinthian Christians in service sectors were not able to leave their working place whenever they decided to. It was also highly probable for them that they might come late to the Christian gathering. They could be poor workers or slaves who worked at those shops. However, they could also be the Roman citizens working in municipal services, owners of business shops, inns, or restaurants, for instance, where the time of leaving the working place depended on the customers' departure or the availability of one's hired workers. Those shops were often run by a whole household, with slaves included. This household business was not classified as poor people living at the subsistence level, and they were also not free to come to the gathering on time. Then they arrived late and found nothing to eat, or they could not manage to go home first to bring their home-made food but had to rush to the meeting place immediately. In any case, there were many possibilities for the freedman participating in trading and service sectors to join in "the hungry group" during the gathering.

\section{Early Comers could be Poor People}

On the other hand, those who came early could also be the jobless or people available to be hired--waiting in the agora or sea-port for temporary jobs on a daily basis. These poor groups could come early to consume all the food offered by the host of the gathering place, or they could go home first to bring food to the gathering place to eat, for they had ample leisure time. Instead, if they could prepare their meals at home in advance, even poor people could have abundant

William Loader, Boris Repschinski, Eric Wong (Eds.)

Matthew, Paul, and Others: Asian Perspectives on New Testament Themes

(C) 2019 innsbruck university press, ISBN 978-3-903187-66-5, DOI 10.15203/3187-66-5 
material food to fill their stomach. It is because the Mediterranean diet could be obtained and made by most of the peasants in the city. The main components of the Mediterranean diet in antiquity were the triad: cereals, vines and olives. They were all available in urban cities, especially in the city with abundant goods like Roman Corinth. In particular, cereals were ubiquitous for poor people. Although poor people might not be able to purchase meat, they could obtain dry legumes like broad beans, chickpeas, lentils and peas as "the poor man's meat" (Garnsey, 1999, pp. 13-15). In sum, though the quality of the food may be low, the poor (if they had time to do it at home in advance) could make a meal that filled up their stomach.

Thus, when the first readers listened to Paul's rhetorical question in v.22: "Or do you despise the church of God, and shame those who have nothing," the first readers would probably identify the group being shamed simply as those late comers composed by both rich and poor.

\section{House Structure Against Rich-poor Reading}

One piece of archaeological evidence often cited as support for the "rich-poor" notion is the interior house design found in antiquity. The historical setting of house gathering in 1 Cor 11: 17-34 has been explained on the basis of the structure of a villa found in Anaploga near Corinth. The interior design of Anaploga villa was divided into the triclinium, atrium and peristylum. As the dining room (triclinium) was not spacious, the host might follow the social norms to arrange the social superiors to dine comfortably in the dining room, while the majority of lower classes stood and had their meals in the atrium or peristylum. As those who were in the dining room had access to the food first, the majority of Christ-followers standing outside might not have food to eat. This archaeological setting of house design has been taken as further support of the picture of social inequality taking place during the love feast before or during the Lord's Supper (Murphy-O'Connor, 1983, pp. 153-161). This house scenario was also key evidence cited to support the notion of competition for honour from members of different social status (Chester, 2003, pp. 249-252; Fuad, 2019, pp. 206-207).

However, the recent archaeological study of houses in antiquity has shown that this villa was not a standard model of homes of ordinary people in the first century. David Horrell (2004, p. 354) points out that the mosaic pictures found

William Loader, Boris Repschinski, Eric Wong (Eds.)

Matthew, Paul, and Others: Asian Perspectives on New Testament Themes

(C) 2019 innsbruck university press, ISBN 978-3-903187-66-5, DOI 10.15203/3187-66-5 
in this villa did not exist until the third century CE. This discovery throws doubt on the plausibility of Murphy-O'Connor's reconstruction of the house scenario of the Lord's Supper in the first century CE. This villa was unusually luxurious compared with houses commonly found in archaeological sites of $1^{\text {st }}$ century Roman Corinth. Therefore, I concur with Horrell's (2004, pp. 356, 359) modest summary of his evaluation on Murphy-O'Connor's house division scenario:

None of this renders Murphy-O'Connor's imaginative scenario impossible, of course, but there is a further reason to question its plausibility, related to his depiction of the findings as concerning 'a typical house'.... They are thus unlikely to be 'typical', at least insofar as typical is taken to refer to the kind of dwellings in which the majority of the population might have lived....It is at the very least uncertain whether any of the Corinthian Christians, and their 'host' Gaius in particular, would likely have owned a large, sumptuous villa.

Without this clear picture of the interior division of space for Corinthian church gathering in 1 Cor 11: 17-34, the rich-poor notion or the contention of competition for honour lacks the very base for the further arguments about the misbehaviour of Corinthians in the Lord's Supper. ${ }^{4}$

Besides the uncertainty of the house setting of this early Christian gathering, the notion of competition for honour seems to be at odds with Paul's rhetoric in the text. From a critical rhetorical analysis of the text itself, Paul did not blame the host per se. Paul's main thrust was to rebuke and correct the misbehaviours of the whole group in their participation in the Lord's Supper. No matter where it took place, the early comers, not the host, did not care about the latecomers and consumed all the food, either the food offered by the host or their food prepared in advance and brought to the gathering. They were not considerate towards the needs of latecomers and so left the latecomers to become a hungry group in which both rich and poor members or members of high and lower status were included. This divisive act was what Paul sought to correct, and the behaviour Paul expected from them after correction is this: "So then, my brothers, when you come together to eat, wait for one another " $\Omega \sigma \tau \varepsilon, \alpha \dot{\alpha} \delta \varepsilon \lambda \varphi$ oí

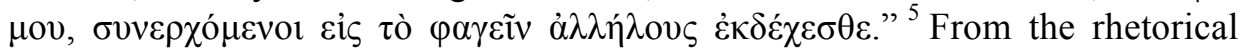

4 Recent historical studies of early Christian gatherings point towards the possibility that they gathered not in homes but in public places. For instance, they might meet in taverns (Weissenrieder, 2012, pp. 70-73) or in the garden (Balch, 2012).

5 For other convincing arguments against the notion of "rich-poor division", see Meggitt (1998, pp. 118-122).

William Loader, Boris Repschinski, Eric Wong (Eds.)

Matthew, Paul, and Others: Asian Perspectives on New Testament Themes

(C) 2019 innsbruck university press, ISBN 978-3-903187-66-5, DOI 10.15203/3187-66-5 
analysis of the text itself, it is difficult to imagine a competition of honourable seats or positions took place during the meal.

In all, the problem that made attendants hungry was not the scarcity of food nor the competition for honour among the members. It is not about the conflict between the rich and poor in terms of unequal material wealth or social status from different social class. After all, Paul's resolution in his ensuing teachings about the Lord's Supper does not address any of these problems, as Lanuwabang Jamir (2016, p. 130) aptly observes: "If those stratifications were the reason for the conflict, Paul does not correct the inequities; in 11:33-34, he simply advises them to eat at their homes."

I contend that the habitus of the first readers of pagan association idol worship meals, both practices and perceptions, resulted in their division and confusion during the Lord's Supper. The former idol worship mentality was probably another "old leaven" (1 Cor 5: 6-8) Paul urge them to clean out, some old habits or perceptions that both rich and the poor had held for years as idolworshippers before they believed in Christ.Paul has persuaded them to flee from idol meals throughout 1 Corinthians 8-10. Here, Paul continues to correct them over some of their idolatrous habits which resulted from past (or even present) participation in idol meals.

\section{Getting Rid of Idol Meals' Old Habitus}

At the beginning about this issue of division in the Lord's Supper in 11:19, Paul assumes that this division is necessary for the first readers, so that those who are approved may be distinguished among them. Stephen Chester (2003, p. 247) has aptly pointed out this overlooked problem in the interpretation of the Lord's Supper:

Theissen's straightforward division between the rich and the poor assigns to the poor an essentially passive role, and to the rich an unworthy one. Thus, from Paul's perspective, the rich have been discredited, but which group have been revealed (

The ongoing issue about genuine faith in Christ reasonably refers to idol meals just mentioned before in 1 Cor 8-10. Paul deems the question about attending idol meals as a test of the genuine faith in one God one Lord (8:6) of the first readers as distinct from those who were still confused (Ho, 2015, pp. 154-169). In particular, Paul contrasts table of the demons with the Lord's in 1

William Loader, Boris Repschinski, Eric Wong (Eds.)

Matthew, Paul, and Others: Asian Perspectives on New Testament Themes

(C) 2019 innsbruck university press, ISBN 978-3-903187-66-5, DOI 10.15203/3187-66-5 
Cor 10:19-22 to remind them of the sole allegiance to the Lord Jesus Christ entailed in their participation in the Lord's Supper (Ho, 2015, pp. 201-202).

This rhetoric of either-or pattern exists again in 1 Cor 11:19. Paul deems the nature of the division primarily as a test of genuine faith in the Lord. The term "division" in 11:19 is not $\sigma \chi i \sigma \mu \alpha \tau \alpha$ in 11:18, which means merely group

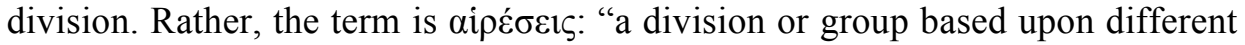
doctrinal opinions and/or loyalties and hence by implication in certain contexts an unjustified party or group" (L\&N, 1, 129). It is usually translated as heresy, denoting a group of deviant insiders who go astray from the beliefs of the speaker (e.g. Acts 24:5, 14; Gal 5:20; 2Pe 2:1).

Paul's ongoing teaching about the Lord 's Supper in the ensuing context (11:23-25) confirms this understanding. His constructive teachings on the Lord's Supper are NOT primarily the rhetoric of mutual love or social integration per se. Paul does not even mention any word related to "loving your brothers" or "loving your neighbours". Paul places the teaching of love in two chapters later concerning the way of utilizing spiritual gifts, but terminologies or phrases about brotherly love are not present here after Paul's rebuking their divisions in the Lord's supper. The key verbs that define acts of love in 1 Cor 13:4-8 are almost all absent in Paul's teachings about the Lord's Supper in 1 Cor $11 .{ }^{6}$ On the other hand, there are numerous literary parallels between 10:16 and 11:23-25, as rightly observed by Jonathan Schwiebert (2008, p. 32) and systematically delineated by Chelcent Fuad (2019, p. 211):

The only exceptional parallel is the verb $\pi \_\sigma \tau \varepsilon v \omega$ in 13:7 and $11: 18$. But this verb 'believe' is so common throughout 1 Corinthians ( 9 times). In 11:18 it refers to what Paul believes about the problems of the divisions taking place in the Lord's Supper in 11:18 and not about Paul's teachings on that issue.

William Loader, Boris Repschinski, Eric Wong (Eds.)

Matthew, Paul, and Others: Asian Perspectives on New Testament Themes

(C) 2019 innsbruck university press, ISBN 978-3-903187-66-5, DOI 10.15203/3187-66-5 
Table 1. Parallels between 1 Cor 11:23-25 and 1 Cor 10:16.

\begin{tabular}{|c|c|}
\hline 1 Corinthians $11: 23-25$ & 1 Corinthians $10: 16$ \\
\hline 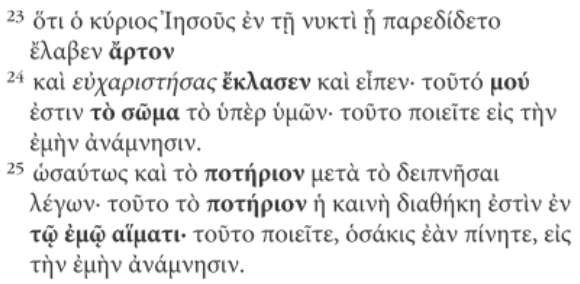 & 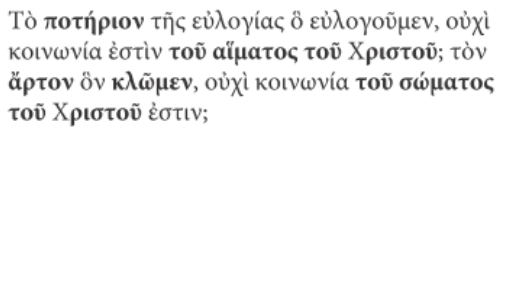 \\
\hline $\begin{array}{l}23 \text { the Lord Jesus on the night when he was } \\
\text { betrayed took bread, } \\
24 \text { and when he had given thanks, he broke it, } \\
\text { and said, 'This is my body which is for you. } \\
\text { Do this in remembrance of me.' } \\
25 \text { In the same way also (he took) the cup, after } \\
\text { supper, saying, 'This cup is the new covenant } \\
\text { in my blood. Do this, as often as you drink it, } \\
\text { in remembrance of me.' }\end{array}$ & $\begin{array}{l}\text { The cup of blessing that we bless, is it not } \\
\text { a participation in the blood of Christ? The } \\
\text { bread that we break, is it not a participa- } \\
\text { tion in the body of Christ? }\end{array}$ \\
\hline
\end{tabular}

From his constructive teachings of the Lord's Supper after 11:22, it is plausible that in addressing these divisions Paul was continuing his anti-idol polemic in 1 Cor 10 to rebuke some false beliefs of his first readers in the Lord's Supper.

I do not argue that Paul's teachings about the Lord's Supper exclude all possibilities of practising mutual love. Rather, it is undeniable that Paul's choice of words primarily focuses on the correct understanding and beliefs in the Lord's Supper, NOT mutual love or social integration per se.

Besides the formal literary parallels of 1 Cor 11:23-25 and 10:16, the identity of the "heresy" group in 11:19 may emerge according to the contents of constructive teachings about the Lord's Supper on and after 11:23. Paul utilises Jesus' sayings in the Last Supper narrative in Jerusalem to teach Corinthians (former idol-worshippers) about some of the attitudes he sees in the evening Christian gathering in Roman Corinth. Paul focuses on the Lord's Supper as a proclamation of the Lord's death (11:26), not the ways how Christian community members should treat each other. Paul conveyed this conviction through the participatory act of Lord's supper. If Paul's main teachings about the Lord's Supper is about conviction, it is reasonable to regard the faults related to the divisions/heresy as relating to some wrong convictions or values. 
These false convictions have led them to despise the whole church of God and shame those who have nothing to eat in the gathering.

Paul's citation in 11:25 of Jesus' sayings in the Last Supper in Jerusalem further points out the long Jewish tradition of parallels between the covenantabiding faithfulness of God's people and abandonment of idolatrous practices. Scholars have generally accepted that Jesus' sayings in 11:25 echo or at least allude to Exod 24:8 or Jer 31:31 (Collins, 1999, p. 433; Garland, 2003, p. 547; Fitzmyer, 2008, p. 443; Ciampa \& Rosner, 2010, p. 552; Fee, 2014, p. 614). The literary context of Jeremiah recalls the monotheistic confession that the people of God should be faithful to Yahweh: I will be their God, and they will be my people (Jer 31.33). The preceding context of Exod 24, in particular, Exod 23:23-24, presents the serious warnings that they should not worship the gods of the inhabitants of Canaan and they should destroy all their gods. The echoes of Jewish Scripture of Jesus' sayings in the Last Supper continue to remind them of the apostasy of the first generation Israelites in the wilderness, to which Paul has explicitly appealed in 1 Cor 10:1-22. This implies that the false values that resulted in their divisions/heresies may also be related to some habits or worldviews from their former idol worship practice, even though they were now participating in the cultic meals of Jesus Christ.

If Paul preaches anti-idol rhetoric in his instructions to male worship leaders (men praying and prophesying in the gathering) by commanding them not to cover their head in 11:1-16, ${ }^{7}$ this motif continues in his instructions of the Lord's Supper as well as the beginning of his discussion about utilizing spiritual gifts in worship gathering (12:1-3). While the former addresses worship leaders, telling them that they should get rid of their old mindset of priests in pagan worship, the latter addresses the whole congregation. Paul instructs them to cleanse from themselves their old mentality of receiving blessing gifts from gods and embody their new faith in Christ in the way they participate in the cultic meal with the Lord Jesus Christ.

For the reasons for reckoning the instructions of unveiling men's head in praying and making prophecy as antiidol polemic, see 何善斌, 2018, pp. 153-177; Finney, 2010, pp. 36-38; Gill, 1990; Oster, 1988, p. 496.

William Loader, Boris Repschinski, Eric Wong (Eds.)

Matthew, Paul, and Others: Asian Perspectives on New Testament Themes

(C) 2019 innsbruck university press, ISBN 978-3-903187-66-5, DOI 10.15203/3187-66-5 


\section{Conclusion}

Gerd Theissen's notion of rich-poor disparity had been taken for granted as the explanation of the divisions which had taken place in the Lord's Supper in 1 Corinthians 11. Following Theissen's socio-historical approach by taking into consideration Roman Corirnth's economic activities as an entrepôt, and its role as a civil administration centre and tourist centre for the empire-wide Isthmian games, I come to a different conclusion. The latecomers could be rich (e.g. shop owners, merchants) or poor (e.g. slaves, transport workers) who were not free to control their working hours. The early comers who could manage to go home first and then come to the gatherings could be rich or also poor (e.g. jobless). Through a rhetorical analysis of 1 Cor 11:17-34 (mainly vv.17-22), I have argued that their old behaviour associated with idol meals is the major irregularity which Paul targets to rebuke and correct in his teachings about the Lord's Supper. Paul continues to combat against old habitus, both practices and perceptions associated with idol worship, in his teachings of head covering in 11:1-16 (to worship leaders), the Lord's Supper in 11:17-34 (to the worshipping congregation), and this is probably also the case in his teaching of spiritual gifts in 1 Cor 12-14 (cf. 12:2-3). He continues to make a case for the new mentality and theology of worship which is to characterise Christ-followers who confess one God (the Father) one Lord (Jesus Christ) in 8:6.

Paul's teachings of worship in 1 Cor 11-14 echo his metaphor of old heaven in 1 Cor 5:7: "Cleanse out the old leaven so that you may be a new batch, as you really are unleavened. For our paschal lamb, Christ, has been sacrificed." Paul applies this command to the distinctive mindset of Christian worship in the participation of the cultic meals with Jesus Christ.

This paper commends further socio-religious study and comparison of the concept and practice of cultic meals in the Mediterranean world and worship of Christ-followers depicted in 1 Cor 11-14. The investigation of the meanings of cultic meals in the idol worship ritual in antiquity may enable us to learn more about the nuanced difference in mentality between idol worship and Godworship of Christ-followers. As a result, it may bring new insights to Paul's teachings of the Lord's Supper, and consequently his theology of worship throughout 1 Cor 11-14.

William Loader, Boris Repschinski, Eric Wong (Eds.)

Matthew, Paul, and Others: Asian Perspectives on New Testament Themes

(C) 2019 innsbruck university press, ISBN 978-3-903187-66-5, DOI 10.15203/3187-66-5 


\section{Bibliography}

\section{Sources}

Slusser, Michael. (Ed.) (2003). [Justin Martyr's] Dialogue with Trypho, selections from the fathers of the church, vol. 3. Translated by Thomas B. Falls. Revised and with a New Introduction by Thomas P. Halton. Washington, D.C.: Catholic University of America.

Roller, Duane W. (Trans.) (2014). The geography of Strabo: An English translation, with introduction and notes. Cambridge: Cambridge University Press.

\section{Secondary Literature}

Alikin, Valeriy A. (2010). The earliest history of the Christian gathering: Origin, development and content of the Christian gathering in the first to third centuries. Leiden: Brill.

Balch, David L. (2012). The church sitting in a Garden (1 Cor 14:30; Rom 16:23; Mark 6:39-40; 8:6; John 6:3, 10; Acts 1:15; 2:1-2). In David L. Balch and Annette Weissenrieder (Eds.), Contested Spaces: Houses and temples in Roman antiquity and the New Testament (pp. 59-107). WUNT 285. Tübingen: Mohr Siebeck.

Chester, Stephen J. (2003). Conversion at Corinth: Perspectives on conversion in Paul's theology and the Corinthian church. London: T\&T Clark.

DeSilva, David (2000). Honor, patronage, kinship and purity: Unlocking New Testament culture. Downers Grove, III: IVP.

Fee, Gordon D. (2014). The first epistle to the Corinthians. Revised Edition. NICNT. Grand Rapids, Eerdmans.

Finney, Mark T. (2010). Honour, head-coverings and headship: 1 Corinthians 11.2-16 in its social context. JSNT, 33(1), 31-58.

. (2012). Honour and conflict in the ancient world: 1 Corinthians in its Greco-Roman social setting. Library of New Testament Studies 460. London, New York: T\&T Clark International.

Fuad, Chelcent (2019). The practice of the Lord's Supper in 1 Corinthians 11:17-34 as a socio-religious ritual failure. ExpT, 130(5), 202-214.

Garland, David E. (2003). 1 Corinthians. Baker Exegetical Commentary on the New Testament. Grand Rapids: Baker Academic. 
Garnsey, Peter (1999). Food and society in classical antiquity. Cambridge: Cambridge University Press.

Gill, D. W. J. (1990). The importance of Roman portraiture for head-coverings in 1 Corinthians 11:2-16. TynB, 41, 245-260.

Hays, Richard B. (1997). First Corinthians. Interpretation. Louisville: Westminster John Knox.

Ho, Sin-pan D. (2015). Paul and the creation of a counter-cultural community: A rhetorical analysis of 1 Cor. 5-11.1 in light of the social lives of the Corinthians. Library of New Testament Studies 509. London, New York: Bloomsbury T\&T Clark.

Horrell, David (2004). Domestic space and Christian meetings at Corinth. NTS, 50, 349-369.

Jamir, Lanuwabang (2016). Exclusion and judgement in fellowship meals: The sociohistorical background of 1 Corinthians 11:17-34. Eugene: Pickwick.

McRae, Rachel M. (2011). Eating with honor: The Corinthian Lord's Supper in light of voluntary association meal practices. JBL, 130, 165-181.

Meggitt, Justin (1998). Paul, poverty and survival. Edinburgh: T\&T Clark.

Meeks, Wayne A. (1983). The first urban Christians: The social world of the apostle Paul. New Haven and London: Yale University Press.

Mitchell, Margaret M. (1991). Paul and the rhetoric of reconciliation: An exegetical investigation of the language and composition of 1 Corinthians. Tübingen: Mohr Siebeck.

Murphy-O'Connor, Jerome (1983). St. Paul's Corinth: Texts and archaeology. Wilmington: Glazier.

Oster, Richard (1988). When men wore veils to worship: The historical context of 1 Corinthians 11.4. NTS 34, 481-505.

Pettegrew, David K. (2014). The Diolkos and the Emporion: How a land bridge framed the commercial economy of Roman Corinth. In Steven J. Friesen, Sarah A. James \& Daniel N. Schowalter (Eds.), Corinth in contrast: Studies in inequality (pp. 126-142). NovTS 155. Leiden: Brill.

Schwiebert, J. (2008). Knowledge and the coming kingdom: The Didache's meal ritual and its place in early Christianity. Library of New Testament Studies 373. London: T\&T Clark.

Theissen, Gerd (1982). Social integration and sacramental activity: An analysis of 1 Cor. 11:17-34. In John H. Schütz (Ed. and Translated and with an Introduction), The social setting of Pauline Christianity: Essays on Corinth (pp. 145-174). Philadelphia: Fortress.

William Loader, Boris Repschinski, Eric Wong (Eds.)

Matthew, Paul, and Others: Asian Perspectives on New Testament Themes

(C) 2019 innsbruck university press, ISBN 978-3-903187-66-5, DOI 10.15203/3187-66-5 
Weissenrieder, Annette (2012). Contested spaces in 1 Corinthians 11:17-33 and 14:30: Sitting or reclining in ancient houses, in associations and in the space of ekklēsia. In David L. Balch and Annette Weissenrieder (Eds.), Contested Spaces: Houses and temples in Roman antiquity and the New Testament (pp. 59-107). WUNT 285. Tübingen: Mohr Siebeck.

何善斌、張達民 (2018)。《哥林多前書 (卷下)》。天道聖經註釋。香港 $\square$ 天道。 